\title{
Mário Chamie: \\ o poeta em busca de novas formas de comunicação
}

Adilson Citelli

Professor titular do Departamento de Comunicações e Artes da ECA/USP, onde ministra cursos de graduação e pós-graduação. Orienta dissertações e teses nas áreas de Comunicação e Linguagem, com ênfase nas subáreas Comunicação/Educação, Comunicação/Linguagem. É coeditor da revista Comunicação Ẽ Educação, bem como pesquisador 1 C do CNPq e autor de inúmeros artigos e livros, dentre os quais se destacam: Linguagem e Persuasão (Ática, 1994); Comunicação e Educação: a linguagem em movimento (Senac, 2000); Palavras, meios de comunicação e educação (Cortez, 2006).

"Sou Chamie, Mário, franco-egípcio é o meu passado."

O poeta, crítico, ensaísta e professor Mário Chamie nasceu no dia 1ำ de abril de 1933, na cidade de Cajobi, interior do Estado de São Paulo, e morreu em 3 de julho de 2011, na capital paulista. Ainda jovem, em 1948, veio para São Paulo para trabalhar como office boy e prosseguir nos estudos, que incluíram o curso clássico no Colégio Roosevelt e a Faculdade de Direito no Largo do São Francisco, concluída em 1956. Em 1994 defendeu o doutorado em Literatura na UFRJ.

A obra poética de Mário Chamie é vasta, com 13 livros publicados entre 1955 e 2002. Os seus textos estão traduzidos em 12 idiomas. Vinculado nos primeiros anos de sua produção literária aos concretistas, deles se afasta em 1961, por pretender maior engajamento da poesia nos temas sociais e políticos. Essa divergência foi traduzida por Mário Chamie na criação do movimento conhecido como Poesia Práxis (Instauração Práxis). Daí decorreu o livro Lavra Lavra, de 1962, com o qual ganhou o prêmio Jabuti de poesia. Acerca da Poesia Práxis, assim se manifesta o autor em entrevista dada ao Projeto Memória Oral, da Biblioteca Mário de Andrade1: "Práxis: fazer e refazer constantemente as coisas, os signos, as pessoas, as emoções, os sentimentos, as palavras, em busca de novos, surpreendentes e contraditórios significados, porque o mundo não é uma inércia adormecida, o mundo não é uma lesma que tomou Lexotan, o mundo é uma coisa vigorosa".

Mário Chamie desempenhou, ainda, funções públicas como a de Secretário da Cultura do Município de São Paulo (1979-1983), tendo inaugurado o Centro Cultural São Paulo. Atuou em televisão (Programa Dimensão 2. TV. Cultura) e rádio (Programa 50 por 1. Rede Record). Foi membro da Academia

1. Disponível em: <http:// www.prefeitura.sp.gov. br/cidade/upload/Depoimento_Mario_Chamie_1256675522.pdf>. 
Paulista de Letras. Exerceu o magistério na Escola Superior de Propaganda e Marketing, desde 2004 até a proximidade da morte, ministrando a disciplina de Comunicação Comparada.

\section{POEMAS}

A seguir apresentamos quatro poemas de Mário Chamie. Os dois primeiros foram publicados em Lavra Lavra, e indicam um vetor ao mesmo tempo de inovação formal e preocupação com as temáticas sociais.

\section{Lavra Dor}

I

Lavra: onde tendes pá, o pé e o pó, sermão da cria: tal terreiro.

Dor: Onde tenho pó, o pé e a pá, quinhão da via: tal meu meio de plantar sem água e sombra.

Laura: Onde está o pó, tendes cãibra;

agacho dói ao rés e relva.

Dor: Onde, jaz o pó, tenho a planta

do pé e milho junto à graça

do ar de maio, um ar de cheiro.

Lavra: A planta e o pé, o pó e a terra;

o mapa vosso; várzea e erva.

II

Dor: Onde o ganho alastra eu perco.

Perde o mapa a cor, fina réstia

de amanho em nós, nossa rédea

III

de luz lastro em casa, o raso

nosso e a fome clara verga

o corpo onde o ganho alastra.

Lavra: A planta e o mapa, pó e safra

Dor: Onde a morte perde, em ganho.

Ganha a casa amor, o pouco

de amanho em nós, já redobro

de paz aura em casa, o raso

nosso e a fome cava cede

no corpo, onde a morte perde.

Lavra: Mapa vosso, várzea e erva,

domingo e sol um voo narra.

Dor: Onde é a mó, mais moeda má, ardendo, ardente ira, nós, o veio, nosso sangue, vaza.

Lavra: Mapa vosso, várzea e safra. Dor: Onde é o pó, cultivo raia.

Pó arroz outona. Acelera

o sol não o voo mas a raiva

nossa, lenta mó que esmaga

a lavra a dor, a mão e o calo.

E orando, aramos, sem sombra,

se arados somos

no valo. 


\section{Plantio}

\section{Cava}

então descansa.

Enxada; fio de corte corre o braço

de cima

e marca: mês, mês de sonda.

Cova.

Joga,

então não pensa.

Semente; grão de poda larga a palma de lado

e seca; rês, rês de malha.

Cava.

Calca

e não relembra.

Demência; mão de louco planta o vau de perto

e talha: três, três de paus.

Cova.

Molha

e não dispensa.

Adubo; pó de esterco mancha o rego de longo

e forma: nó, nó de resmo.

Joga.

Troca,

então condena.

Contrato; quê de paga perde o ganho de hora

e troça: mais, mais de ano.

Calca.

Cova:

e não se espanta.

Plantio; fé e safra sofre o homem

de morte

e morre: rês, rés de fome

cava.

\section{Agiotagem}

Um

Dois

Três

o juro: o prazo

o pôr / o cento / o mês / o ágio

porcentagio.

$d e z$

muito

nada

cem

mil

o lucro: o dízimo

o ágio / a mora / a monta em péssimo

e mpréstimo.

tudo

a quebra: a sobra

a monta / o pé / o cento / a quota

h a ja not $a$

agiota. 
comunicação \& educação • Ano XVIII • número 2 • jul/dez 2013

\section{Siderurgia S.O.S.}

Se der o ouro sidéreo opus horáriO

Sem sol o sal do erário salário

Ser der orgia semistério o empresáriO

Siderurgia do opus o só do eráriO

Se der a via do pus opus erradO

Se der o certo no errado o empregadO

Se der errado no certo o emprecáriO

\section{REFERÊNCIAS BIBLIOGRÁFICAS}

CHAMIE, Mário. Lavra dor e plantio. In: Lavra lavra. São Paulo: Massao Ohno, 1962.

. Agiotagem e siderurgia S.O.S. In: Indústria. São Paulo, Mirante das Artes, 1967. 